\title{
Cytoskeletal Organization and Rb Tumor Suppressor Gene
}

\author{
Yi-Jang Lee ${ }^{1, *}$, Pei-Hsun Chiang ${ }^{1}$ and Peter C. Keng ${ }^{2}$ \\ ${ }^{1}$ Department of Biomedical Imaging and Radiological Sciences, \\ National Yang-Ming University, Taipei \\ ${ }^{2}$ Cancer Center, School of Medicine and Dentistry, \\ University of Rochester, Rochester, NY \\ ${ }^{1}$ Taiwan, R.O.C. \\ ${ }^{2} U S A$
}

\section{Introduction}

Cell cycle progression is dependent on a series of molecular regulation after cells are stimulated by growth factors. Growth factors bind to corresponding surface receptors and relay the signals through protein phosphorylation to trigger gene expression. Phosphorylation of retinoblastoma protein $(\mathrm{Rb})$ is to release E2F family of transcription factors for DNA replication. In adherent cells, the actin filament plays an important role for anchorage, locomotion, morphological maintenance, and cell division (1). These mechanical characteristics influence cell cycle progression, and mediate cells responding to extracellular stimulations. The cyclin-dependent kinases (CDKs) are responsible for cell cycle transition through different phases. For G1 phase progression, the G1 cyclins associated CDKs can phosphorylate and inactivate $\mathrm{Rb}$. Because the phosphorylation sites of $\mathrm{Rb}$ are multiple, they become a family of checkpoint to prevent release of E2F transcription factor under a stress condition, such as DNA damage. In addition, the CDKs activity and Rb phosphorylation are ablated by the family of CDK inhibitors (CKIs), including INK4 and CIP/KIP family proteins (2). The underlying mechanisms by which the intact actin filaments regulated cell cycle progression have been reviewed in literatures, although the pathways are diverse from different research results. However, it appears that $\mathrm{Rb}$ activity is commonly affected by destabilizing the actin cytoskeleton. Therefore, it is believed that growth factor stimulated actin cytoskeletal organization can regulate $\mathrm{Rb}$ activity for $\mathrm{G} 1$ phase progression and DNA replication.

Although actin cytoskeletal organization affects $\mathrm{Rb}$ activity, the cell cycle regulatory components have been recently reported to influence actin organization and cell motility (3). It is largely associated with CIP/KIP family proteins when they relocate to cytoplasm from nucleus. They inhibit Rho small GTPase family protein for actin architectures formation. Interestingly, $\mathrm{Rb}$ may regulate $\mathrm{CIP} / \mathrm{KIP}$ protein expression through E2F transcriptional activity (4), and this observation implies that an autoregulatory mechanism may exist

* Corresponding Author 
between actin cytoskeletal organization and $\mathrm{Rb}$ for regulating cell growth and cell cycle progression. Investigation of these biological events would contribute to cancer research and therapeutic design for cancer treatment or prevention.

\section{Actin cytoskeletal reorganization during cell cycle progression}

The cytoskeleton consists of three different types of cytosolic fibers that include actin filaments (also named microfilaments), intermediate filaments, and microtubule. Of the three types of fibers, actin filaments are primarily responsible for cell mobility, anchorage, and shape maintenance. Actin filaments are formed by polymerizing the ATP-bound actin subunits, so called G-actin, through a energy-required dynamic process. Actin filaments can be organized into different types of actin cytoskeletons including stress fibers, lamellipodia, and filapodia distributed in different regions of cells for specific functions. It is well-known that Rho small GTPase family proteins are responsible for actin organization. Organization of actin filaments is associated with cell growth depending on cell adhesion and mitogenic stimulation (5).

Accumulated evidences have supported the essence of actin cytoskeleton for cell division and proliferation. In fibroblasts, addition of growth factors or other mitogenic stimulation can promote the generation and reorganization of actin cytoskeleton through the small $\mathrm{G}$ proteins, including Rac, Cdc42, and Rho (6). Rac and Cdc42 are important for formation of lamellipodia and filapodia at the leading edges of cells, while Rho is responsible for formation of stress fibers. Actin filaments are organized into different types of actin structures to support cell growth after mitogenic stimulation. Moreover, actin filaments are organized at the focal contacts, in which integrins and other cytoskeletal proteins are present for cell attachment (7). Formation of focal contacts is important for activating a series of signaling pathways such as phosphatidylinositol 3-kinase (PI3-kinase) and mitogen-activated protein kinase (MAPK) pathways $(8,9)$. Actin filaments are important for transducing signals from extracellular matrix into cells for growth. Inhibition of actin filaments after cell attachment leads to blockage of signaling pathways and subsequent growth arrest (10-12). Actin filaments and cell adhesion are also important for cell cycle progression (13). It has been reported that cells with disorganized actin architecture are unable to initiate DNA synthesis (14). Therefore, it appears that actin filaments are important for cell growth and normal cell cycle progression.

Actin filaments are also important for cell division at the telophase during mitosis. Myosin II, one of the actin-binding proteins that moves on actin filaments, binds to actin filaments to form the contractile ring at the middle part of the dividing cell and to pull the plasma membrane inward to form a cleavage furrow (15). Disruption of actin filaments at cytokinesis can lead to failure of division and growth arrest. Collectively, organization of actin filaments is associated with cell growth in both cell signaling and structural aspects.

The distribution of actin cytoskeleton in different phase of the cell cycle has been studied more than two decades. Mitotic phase is the most obvious dynamic stage that microtubule and actin cytoskeletal reorganization can be detected. It is broadly accepted that microtubule formed spindles are critical for chromosomal segregation during mitosis. These fine-tune mitotic spindles are then required for driving the cytokinesis, a cell dividing step ablated by the actin filaments and myosin II sliding machine, for separation of the daughter 
cells (16-18). On the other hand, the role of actin filaments on spindle assembly and positioning are less studied. In fact, the theories of actin cytoskeletal formation in mitotic phase are debated. Investigation of actin cytoskeletal organization in higher plant cells such as meristematic root-tip cells of Allium and staminal hairs have shown that the cytoplasmic actin filaments cannot be detected until the entry of cytokinesis (19-21). The last moment for visualizing the actin filaments right before cells entering the mitosis is likely to be the preprophase (22). Reorganization of actin filaments is found at the contractile ring accompanied by the formation of cleavage furrow, while disruption of actin reorganization using cytochalasin leads to mitotic arrest and aneuploid formation (23-25). However, accumulated literatures also demonstrate that actin filaments dramatically influence the mitotic spindle positioning and assembly not only in plant cells but also in fruitflies, C. elegans zygotes, Xenopus embryos and mouse oocytes during syncytial divisions (26-33). The role of actin filaments is to regulate astral microtubule growth and spindle migration by reorganizing in the cortical region (34). Disruption of cortical actin filaments leads to misorientation of spindles and cell cycle arrest (35). Also, myosin-10 and actin filaments play cooperative but distinct functions on the mitotic spindle formation, proper spindle anchoring, spindle pole integrity, spindle length control, and mitotic progression. We looked into the different stages of anaphase and showed that actin cytoskeletal organization also changed and orchestrated with microtubule for cell division (Figure 1). Taken together, it has become clear that the actin cytoskeleton can interact with microtubule organized spindle fibers for mitotic progression and cell divisions.

Although actin cytoskeletal organization has been well-studied in the mitotic phase, the shape variations of actin cytoskeleton in the interphase remain unclear. The interphase of cell cycle includes G1, S and G2 phase. However, the actin organization in each phase is not well described in the literature. Yu et al. investigated the actin dynamics during the cell cycle in suspension-cultured tobacco BY-2 (Nicotiana tabacum L. cv Bright Yellow) cells using a green fluorescent protein (GFP) fused mouse Talin (mTalin) gene, which can indicate the positions of actin cytoskeleton in the plant cells. Their results clearly indicate the positions of cortical actin cytoskeletal networks in the interphase, and they are altered organized and even disappeared before cells enter mitosis and pre-prophase. Instead, the actin cytoskeletons relocalize to the future equatorial plane and centrally located nucleus and vesicles. Therefore, it is believed that actin cytoskeletal organization should vary in different stages of interphase. We have synchronized human non-small lung cancer H1299 cells at G1/S phase boundary using the double thymidine block protocol, and collected cells at different time intervals for staining of actin cytoskeletal organization using the fluorescineconjugated phalloidin. As shown in figure 2, the actin networks concentrated around nucleus during $S$ phase and pre-prophase (Figure 2). The cortical actin cytoskeleton formed in mitotic phase are consistent with the results reported previously (36), while the actin assemblies are also visualized between segregating chromosomes from the early anaphase to telophase. Actins are organized to visible stress fibers in the G1 phase and mediate morphological maintenance and spreading. The actin architectures are also continuously changed in the G1 phase progression. Although the underlying mechanisms remain to be studied for the association between cell cycle and actin cytoskeletal organization, we have found that the level of actin depolymerizing factor cofilin-1, a protein required for actin dynamics and reorganization, is also changed in G1 to S phase progression (unpublished data). The activity of cofilin-1 has been reported to be essential for G2/M phase progression 


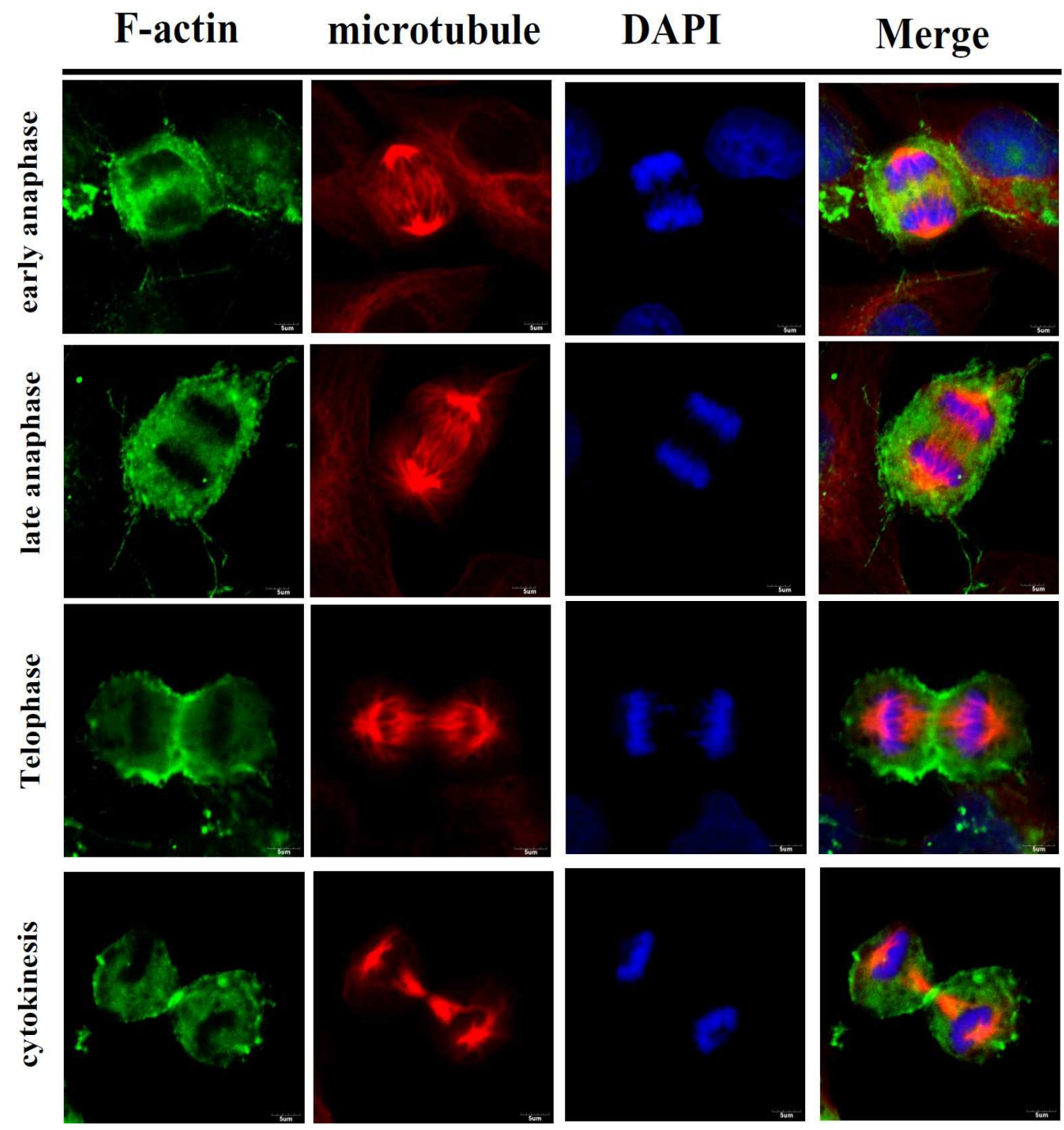

Lee YJ et al.

Fig. 1. Coordination of actin filaments and microtubules for mitotic cells passing from anaphase to telophase and cytokinesis in human non-small lung cancer H1299 cells. The conventional fiber-like structures were not visualized, while the cortical actin cytoskeletons are formed. F-actin was stained by fluorescine-conjugated phalloidin; microtubule was stained by anti-tubulin antibody; DAPI (4',6-diamidino-2-phenylindole) was used for nuclear staining.

$(37,38)$. We have also found that over-expression of cofilin-1 can inhibit G1 phase progression $(39,40)$. Thus, cofilin-1 may regulate actin cytoskeleton not only in the G2/M phase but also in G1 and S phase progression. 
(A)

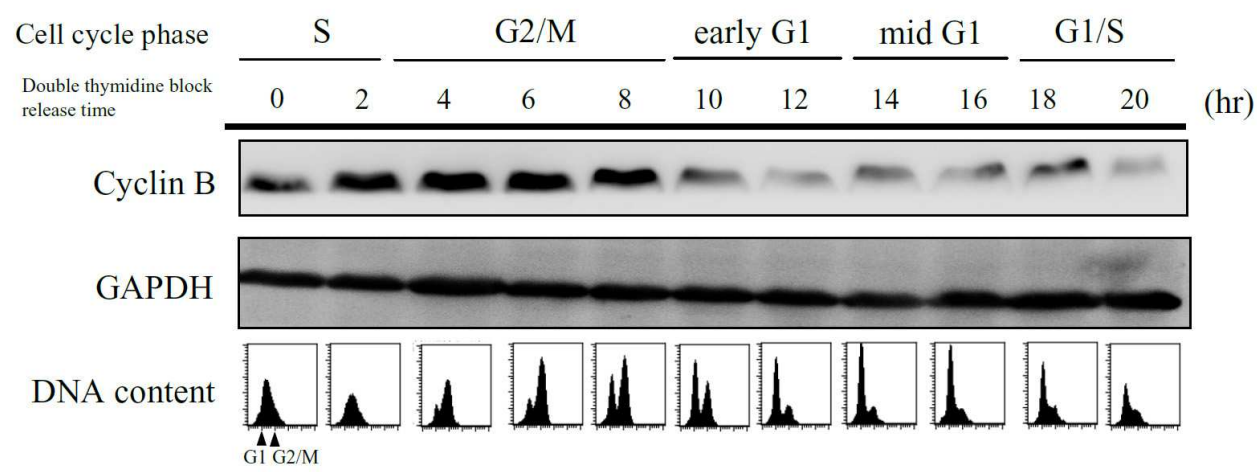

(B)

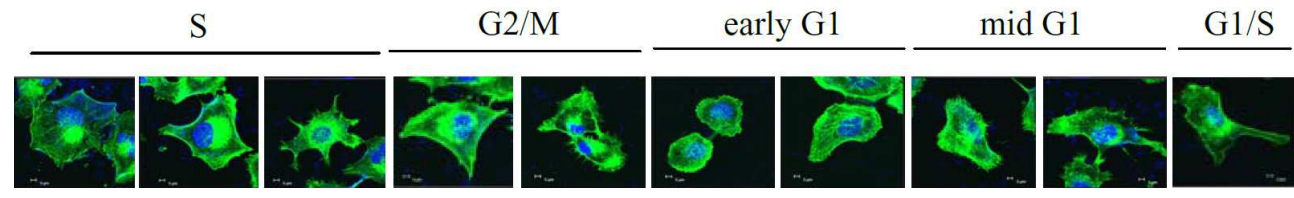

Lee $\mathrm{YJ}$ et al.

Fig. 2. The change of actin architectures during cell cycle progression. H1299 cells were synchronized in S phase using double thymidine block. (A) The cell cycle progression from $S$ phase to next G1/S boundary was demonstrated by DNA histogram and the expression of cyclin B; (B) cells were collected at different stage of the cell cycle and stained for actin cytoskeleton using fluorescine-conjugated phalloidin.

\section{Molecular events for cell cycle progression in mammalian cells}

In eucaryotes, cell proliferation is partially dependent on cell cycle progression. Cyclin and cyclin-dependent kinases (CDK) are required for progression through gap phases (G1 and G2), DNA replication (S), and chromosome segregation (M) phases of the cell cycle. Protein complexes of cyclin and cyclin-dependent kinase (CDK) can phosphorylate specific downstream substrates, including retinoblastoma tumor suppressor protein $(\mathrm{Rb})$ or anaphase-promoting complex (APC), for G1/S or M phase transition, respectively $(41,42)$. The activity of cyclin/CDK for G1 phase progression is regulated by CDK inhibitors, which can bind to cyclin/CDK and inhibit its activity. On the other hand, the CDK inhibitors p21 CIP1 and p27KIP1 are indispensible for cyclin/CDK activity, suggesting that a stoichiometric balance is existed among cyclins, CDKs and CDK inhibitors $(2,43)$. Also, cell 
cycle progression can be inhibited by genotoxic stresses, such as ionizing radiation and some chemotherapeutic agents. In normal cells, activation of tumor suppressor gene p53 is usually involved in this type of response.

Different types of cyclins (A, B, C, D, and E) and CDKs (1, 2, 3, 4, and 6) are responsible for the progression of cells into different stages of cell cycle. Cyclin A binds to CDK2 for S-G2 phase progression, while cyclin B binds to CDK1 for entry into $\mathrm{M}$ phase. The cyclin $\mathrm{C} / \mathrm{CDK} 3$ complex can promote Rb-dependent G0 phase exit (44). Cyclin D binds to CDK4/6 and cyclin E binds to CDK2 for G1 phase progression, although the latter is primarily responsible for late G1 phase or G1-S phase transition. Cyclin D consists of three closely related D-type cyclins, named Cyclin D1, D2, and D3. Expression of different types of cyclin $\mathrm{D}$ for $\mathrm{G} 1$ phase progression is likely to be tissue-specific (45). For G1 to $\mathrm{S}$ phase progression, $\mathrm{Rb}$ is phosphorylated by cyclin D-CDK4/6 and cyclin E-CDK2 to release E2F1, an important transcription factor belonging to the E2F protein family for entry into $S$ phase (46-49). The gene targets of E2F1 are versatile and involved in DNA synthesis and G1/S progression, including DNA polymerase alpha, cyclin E, and E2F1 itself $(50,51)$.

$\mathrm{Rb}$ is a phosphoprotein containing sixteen serine/theronine sites that can be recognized by cyclin/CDKs. Mutations of nine of these consensus phosphorylation sites, including seven sites at the C-terminal and two sites at the insert region of $\mathrm{Rb}$, are sufficient to constitutively active $\mathrm{Rb}$ and block DNA replication (52-54). Also, mutations of this phosphorylation site can cause different cell cycle and apoptotic effects in Rat-16 cells exposed to various stimuli, such as tumor necrosis factor, doxorubicin or staurosporine (55). In addition, $\mathrm{Rb}$ may mediate DNA damage response (DDR). It has been reported that Rb-deficient cells are incapable of cell cycle arrest and are hypersensitive to apoptosis following DNA damage (56). This result suggests that $\mathrm{Rb}$ may protect cells from DNA damage-induced apoptosis. However, phosphorylation of Rb via p38 kinase or ASK1 can inactivate $\mathrm{Rb}$ and promote apoptosis (57-60). These apoptosis-associated phosphorylation sites are independent of those targeted by cyclin/CDKs on Rb (60).

Although $\mathrm{Rb}$ phosphorylation is mainly mediated by D cyclin-CDK4/6 and E cyclin-CDK2 in the G1 phase, high dose of ionizing radiation induced DNA damage can permanently cause G2 phase arrest accompanied by a gradual accumulated hypophosphorylated $\mathrm{Rb}(61)$. Because cyclin B-CDK1 is responsible for G2 phase progression, reduced CDK1 activity is likely to be the cause of hypophosphorylated $\mathrm{Rb}$ in $\mathrm{G} 2$ phase. Interestingly, CDK1 has been reported to be the only essential cell cycle CDK because it can bind to all cyclins and control the $\mathrm{Rb}$ phosphorylation (62). Although it is difficult to demonstrate that cyclin B-CDK1 can mediate $\mathrm{Rb}$ phosphorylation in the $\mathrm{G} 1$ phase, it is plausible that $\mathrm{Rb}$ phosphorylation is ablated by CDK1 in the G2 phase. Actually, Rb phosphorylation is accompanied by the expression of cyclin $\mathrm{B}$ during mitosis. That is, $\mathrm{Rb}$ phosphorylation and cyclin $\mathrm{B}$ are concomitantly decreased from the prophase to telophase of mitosis (63). Besides, it has been reported that phosphorylation of amino terminus of $\mathrm{Rb}$ protein is mediated by a $\mathrm{G} 2 / \mathrm{M}$ phase specific cell cycle-regulated $\mathrm{Rb} /$ histone $\mathrm{H} 1$ kinase (RbK), a kinase exhibits different enzymatic activity compared to CDK1 and CDK2 $(64,65)$. RbK may play a role in G2 checkpoint by controlling the $\mathrm{Rb}$ activity. Taken together, phosphorylation of $\mathrm{Rb}$ protein is important for cell cycle checkpoint at different phases.

$\mathrm{Rb}$ was the first identified tumor suppressor gene. $\mathrm{Rb}$ protein family members include $\mathrm{Rb}$, p130, and p107 genes (66). However, Rb is the only most frequent mutated or deleted gene 
in different types of human cancers $(48,67)$. The functions of $\mathrm{Rb}$ are to sequester E2F family of transcription factors and other proteins associated with apoptosis, DNA damage response, differentiation, protein kinases, hormone regulation, and so on (68-72). Inactivation of $\mathrm{Rb}$ can be approached by optimal phosphorylation on the $\mathrm{Rb}$ protein, or by viral oncoproteins such as E7 protein of human papilloma virus, adenovirus E1A and SV40 large $\mathrm{T}$-antigen that can occupy the pocket domain of $\mathrm{Rb}(48,60,73)$. The extracellular growth factors can bind to the surface receptors and activate ras/raf/mitogenic activated protein kinase (MAPK) cascade, which promote G1 phase progression by activate cyclin DCDK4/6 and cyclinE/A-CDK2 activity. Phosphorylation of Rb by these CDKs not only releases E2F transcription factor but also remodels the chromatin structures by escaping from the repressive functions mediated by histone deacetylation complex (HDAC) and BRG1/BRM ATPase, the human homolog of yeast SWI2/SNF2 chromatin remodeling factors $(60,74-76)$. Mutation or over-expression of surface receptors may over-activate intracellular Ras or myc pathway that constitutively inactivates $\mathrm{Rb}$ for accelerating the G1/S phase progression and leads to tumorigenesis (77). Alternatively, mutation or inactivation of $\mathrm{CDK}$ inhibitors may also lead to excessive inactivation of $\mathrm{Rb}$ even the mitogenic signaling pathway is normally regulated. The role of CDK inhibitors on regulation of cell cycle and $\mathrm{Rb}$ activity is discussed next.

\section{Regulation of cyclin/CDK on Rb inactivation by CDK inhibitors}

The kinase activities of cyclin D-CDK4/6 and cyclin E-CDK2 are required for cells to progress through the G1 phase. Regulation of CDK activity is dependent on the amount of CDK inhibitors (CKIs) in cells. While the basal level of CKI is required for the formation of cyclin/CDK complex and the maintenance of its activity, a high level of CKI tends to inhibit cyclin/CDK activity (78-81). The physical interactions between CKI and cyclin/CDK is required to stabilize or inhibit the activities of CDKs.

Two families of CKIs have been discovered for controlling the activity of cyclin/CDK. One of the families is INK4, which is named for its ability of an inhibition of CDK4 activity. Members of this family are p16INK4a, p15INK4b, p18INK4c, and p19INK4d and they specifically bind to CDK4,or CDK6, but not other CDKs. Members of CIP/KIP family containing broader spectrum inhibition of CDK2 and CDK4/6. This family includes p21CIP1, p27KIP1, and p57kip2, and they can bind to both cyclins and CDKs (2). Although each member of the CKI families can inhibit CDK activity individually, they may also work cooperatively to regulate the G1/S phase progression. For instance, recent reports have suggested that $\mathrm{CIP} / \mathrm{KIP}$ protein bound on CDK4 are released and re-bound to CDK2 by introducing INK4, which replaces the CIP/KIP and binds to CDK4 to cause G1 phase arrest (82-84).

Given that both classes of CDK inhibitors are essential for controlling the cell growth and DNA replication, deregulation of these molecules usually leads to malignancy. Loss of INK4 gene functions has been detected in a variety of human cancers via deletion, mutation or silencing of the chromosomal 9p21 locus (85). An INK4-CDK4/6-Rb regulatory pathway is considered essential for promoting apoptosis and senescence in cells insulted by oncogenic stimuli such as ras (86). INK4 can activate $\mathrm{Rb}$ and sequester E2F transcriptional factor for DNA replication, so loss of INK4 leads to Rb inactivation and carcinogenesis caused by ras over-expression. On the other hand, the CIP/KIP family members are rarely mutated or deleted in human cancers. Instead, their expressions in various cancer cells are reduced 
through mis-regulated post-translational stability, reduced transcription, or even microRNA (3). Although CIP/KIP family proteins are regarded as tumor suppressors because of their cell cycle regulatory role, the subcellular localizations of these proteins may alter their tumor preventive role to completely opposite functions. For example, increased cytoplasmic p27KIP1 level has been found in tumors with higher grade, strong metastatic capacity and poor prognosis, such as breast, cervical, esophagus, uterus cancers, and leukemia/lymphoma (87-90). Also, over-expressed or mislocalized p21CIP1 in cytoplasm is found in advanced and poor prognostic cancers including glioblastoma, carcinomas of prostate, pancreas, breast, cervix, and ovary $(3,91,92)$. The underlying mechanisms are not understood, however, it has been reported that the tumor-promoting functions of CIP/KIP family proteins is likely to be associated with actin cytoskeletal organization and cancer motility (90). The RhoA signaling pathway is influenced by the cytoplasmic CIP/KIP family proteins to reorganize actin networks in cell motility. The detailed mechanisms will be described below. In addition, relocalization of CIP/KIP family proteins from the nucleus to cytoplasm may inactivate $\mathrm{Rb}$ by over-activated CDKs, further explain the tumor-prone manner of such a misregulation $(90,93)$.

Up-regulation of CIP/KIP proteins is usually detected in cells that are insulted by extracellular stimulation, such as inhibition of cell adhesion, addition or removal of mitogens, and ionizing radiation. However, the molecular mechanisms responsible for accumulation of $\mathrm{p} 21^{\mathrm{CIP} 1}$ and $\mathrm{p} 2 \mathrm{KIP}^{1}$ are not identical. Gene transactivation is the primary pathway for up-regulation of p21 CIP1. Many transcriptional responsive elements on the p21 ${ }^{\mathrm{CIP} 1}$ promoter are capable of regulating gene expression in response to different stimulations (94). For example, Sp1 sites on the p21CIP1 gene promoter can respond to phorbol ester (PMA), histone deacetylase inhibitors (TSA), or TGF- $\beta$ for gene transcription. Also, cytokines IL-6 and IFN- $\gamma$ can transactivate the p21CIP1 gene through STAT1 binding sites. In addition, ionizing radiation is able to activate wild-type p53 to transactivate the $\mathrm{p} 21^{\mathrm{CIP} 1}$ gene through the p53 consensus binding sites on the p21CIP1 promoter (95). In response to ionizing radiation, cells with wild-type p53 up-regulates p21 ${ }^{\mathrm{CIP} 1}$ to induce G1 phase arrest (96-98). In contrast to p21CIP1, regulation of p27KIP1 level is dependent on posttranslational control (99). Phosphorylation of p27KIP1 on Thr-187 is dependent on cyclin E/CDK2 and is essential for protein degradation through the ubiquitin-proteasomal mechanism $(100,101)$. It has been reported that SCFSkp2 ubiquitin ligase complex, which is composed of four major subunits (Skp1, Cul1, Rbx1/Roc1, and Fbox protein Skp2), is responsible for degradation of phosphorylated p27KIP1 (102). Inhibition of Thr-187 phosphorylation or Skp2 results in an inhibition of the entry into S phase. Also, another phosphorylation site on p27KIP1 (Ser-10) was reported. In contrast to Thr-187, Ser-10 phosphorylation can increase the stability of $\mathrm{p} 2 \mathrm{~F}^{\mathrm{KIP} 1}$ protein in quiescent cells by promoting nuclear export of p27KIP1 through CRM1/exportin1 (103-106). It can mediate the cytoplasmic relocalization of $\mathrm{p} 27 \mathrm{KIP} 1$ and promote cellular migration induced by hepatocyte growth factor (107). In addition to ser-10 phosphorylation, cytoplasmic localization of p27KIP1 can be induced by phosphorylation of Thr-157 and Thr-198 mediated by Akt/PKB or p90 ribosomal S6-kinase (p90RSK) for certain biological functions that require further investigations $(89,108,109)$. Collectively, it appears that regulation of p27KIP1 and p21CIP1 is mediated by different pathways. Regulation of CDK activity for $\mathrm{Rb}$ function in different phases of cell cycle by cyclins, CKIs and other proteins is summarized in Table 1 (Table 1). 


\begin{tabular}{|c|c|c|c|}
\hline Phase & Cell cycle regulators & Molecular functions $b$ & $\begin{array}{c}\text { Rb activation/ } \\
\text { inactivation }\end{array}$ \\
\hline \multirow[t]{4}{*}{ G0 } & $\begin{array}{l}\text { INK4 (p15 }{ }^{\text {INK4a }}, \mathrm{p} 16^{\text {INK4b }} \\
\text { p18 } \\
\text { INK4c }, \text { p19 INK4d })\end{array}$ & Bind to and inactivate CDK4/6 & activation \\
\hline & p27kip1 & $\begin{array}{l}\text { Binds to and inactivates cyclinD-CDK } 4 \\
\text { complex }\end{array}$ & activation \\
\hline & cyclin C & Binds to and activates CDK3 & inactivation \\
\hline & cyclin D1 & Binds to and activates CDK4/6 & inactivation \\
\hline \multirow[t]{3}{*}{ G1 } & cyclin D2 & Binds to and activates CDK4 & inactivation \\
\hline & cyclin E & $\begin{array}{l}\text { Binds to and activates CDK2, can degrade } \\
\text { p27 }\end{array}$ & inactivation \\
\hline & $\begin{array}{l}\text { CIP/KIP (p21 }{ }^{\text {cip1 }}, \text { p27kip1, } \\
\text { p57kip2) a }^{\text {a }}\end{array}$ & $\begin{array}{l}\text { Bind to and inactivate cyclin D-CDK } 4 \text { or } \\
\text { cyclin E-CDK } 2 \text { complex }\end{array}$ & activation \\
\hline \multirow[t]{2}{*}{ S } & cyclin A & Binds to and activates CDK2 & inactivation \\
\hline & cyclin D3 & Binds to and activates CDK4 & inactivation \\
\hline \multirow[t]{4}{*}{ G2 } & cyclin A & Binds to and activates CDK2 & inactivation \\
\hline & cyclin B1 & Binds to and activates CDK1 & inactivation \\
\hline & $\mathrm{p} 21^{\mathrm{cip} 1}$ & Inhibits CDK1 activity when DNA damage & activation \\
\hline & $\mathrm{Rb} /$ histone $\mathrm{H} 1$ kinase & Phosphorylates the $\mathrm{N}$-terminal of $\mathrm{Rb}$ & undetermined \\
\hline \multirow[t]{4}{*}{ Prophase } & MPF & Promotes cyclin B1 synthesis & inactivation \\
\hline & cyclin B1 & Binds to and activates CDK1 & inactivation \\
\hline & MAPK & Phosphorylates Rb in Xenopus oocytes & inactivation \\
\hline & cdc25 & Activates CDK1 by dephosphorylation & inactivation \\
\hline \multirow[t]{2}{*}{ Metaphase } & MAD2 & Inhibits cyclin B1 degradation & inactivation \\
\hline & BubR1 & $\begin{array}{l}\text { Mad2-interacting proteins for cyclin B1 } \\
\text { degradation }\end{array}$ & activation \\
\hline Anaphase & $\mathrm{APC}$ & Promotes cyclin B1 degradation & activation \\
\hline Telophase & cdc14 & $\begin{array}{l}\text { Activates APC-cdh2 to promote cyclin B1 } \\
\text { degradation }\end{array}$ & activation \\
\hline
\end{tabular}

a. Functions on CDK inhibition may only occur when CIP/KIP binds to cyclin/CDK with more than 1:1 stoichiometry

b. These functions are primarily included but may not be limited.

Table 1. Molecules involved in regulating CDK mediated $\mathrm{Rb}$ activation or inactivation

The cell cycle checkpoint is required to ensure the integrity of the genome during cell cycle progression. The function of the checkpoint is to prevent aberrant DNA from replication or chromosomal segregation. One of the most important regulators for the G1/S checkpoint is p53 $(110,111)$. Under normal physiological conditions, the protein level of p53 is controlled by a specific negative regulator called MDM2, which binds and promotes the degradation of the p53 protein. The activity of MDM2 can be inhibited by p19ARF tumor suppressor, which is a target gene transactivated by E2F transcriptional factor $(112,113)$. Because release of E2F is controlled by $\mathrm{Rb}$ inactivation, the orchestration among the tumor suppressors and potent proto-oncogenes is important for preserving the functions of checkpoint. In response to DNA damage, p53 is phosphorylated and dissociated from MDM2. The p53 protein is 
subsequently resistant to degradation and accumulated in the cells (114). Accumulated p53 enters the nuclei and transactivates the downstream gene p21CIP1 for G1 phase arrest. In the absence of p53, p21CIP1 is not up-regulated and G1 phase arrest is abrogated after DNA damage. The molecular regulation of G1/S phase progression, including a variety of CDKs, CKIs, $\mathrm{Rb}$, and p53, is illustrated in Figure 3.

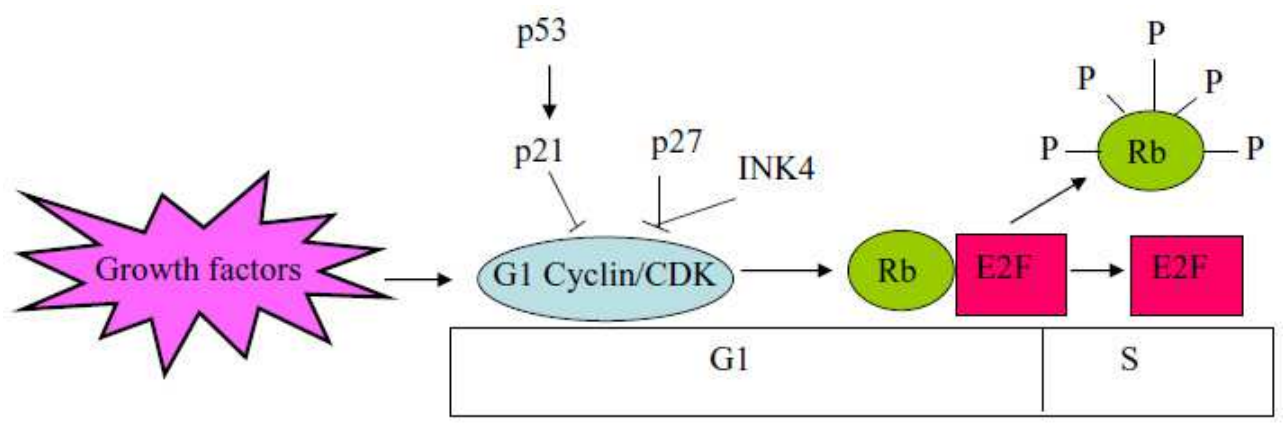

Lee $\mathrm{YJ}$ et al.

Fig. 3. Molecular regulation of cell cycle progression from G1 to $S$ phase. CDK phosphorylates $\mathrm{Rb}$ to release $\mathrm{E} 2 \mathrm{~F}$ transcription factor for $\mathrm{S}$ phase entry and progression. The activity of cyclin/CDK is stimulated by growth factors and is regulated by CDK inhibitors, including p21 ${ }^{\mathrm{cip} 1} / \mathrm{p} 2 \mathrm{kkip}^{1}$ and INK4 family. p53 mediates the expression of $\mathrm{p} 21^{\mathrm{CIP} 1}$ to induce G1 phase arrest, but not p27KIP1 $^{2}$ or INK4 family. INK4 may cooperate with p27KIP1 to induce efficient G1 phase arrest under specific stimulation.

In adhesive cultures, cell attachment is required for entry into the cell cycle. Cells can only be stimulated by growth factor or mitogenic signals after they are anchored onto substratum. Given that actin cytoskeleton is involved in cell attachment and spreading, organization of actin structures may be important for cell cycle progression. The detailed molecular regulation through actin cytoskeletal organization and related biological events are discussed in next section.

\section{Actin cytoskeleton in regulation of $\mathbf{G} 1$ phase progression and Rb activity}

Following cytokinesis, cells enter G1 phase by the presence of growth factors that stimulate a series of signal transduction in cytosol through the surface receptors. The growth factor (or serum)-dependent cell growth includes several events: attachment onto extracellular matrix, spreading, and locomotion. These anchorage-dependent and morphology-dependent effects are important for G1 phase progression and S phase transition. Actin cytoskeletal organization is stimulated by growth factors and is involved in the mechanical and structural mediated cell cycle progression and growth $(13,115,116)$. Also, the time interval of G1 phase is usually long and can be divided into early, mid, and late G1 phase in proliferating cells. The essence of actin cytoskeleton for G1 phase progression, however, is dependent on the stage of G1 phase. For instance, accumulated literatures have shown that intact actin cytoskeleton was required for mid to late G1 phase progression (116-120). Also, serum stimulation and cell anchorage may also be involved in the G1 phase progression (121). Essentially, the actin cytoskeletal organization affects Rb activity in G1 phase 
progression via different signaling pathways. We will elucidate the association between actin networks and $\mathrm{Rb}$ mediated $\mathrm{G} 1$ phase progression according to the literatures reviewed so far.

The organization of actin filaments is believed to be important for initiation of cell growth after cell attachment. Actin inhibitors are routinely adopted for disrupting the actin cytoskeleton in vitro and in vivo. The perturbation of cell cycle was subsequently analyzed by different approaches. The levels of G1 phase arrest were determined from DNA content measured by Feulgen or propidium iodide (PI) staining, or by 5-bromo-2'-deoxyuridine (BrdU) labeling for S phase entry after drug treatment. The significance of actin filaments is to convey the extracellular signals and form an appropriate shape for G1 phase progression (13). It is reasonable that disruption of actin filaments would lead to a G1 phase arrest. Indeed, exposure of cultured cells to sublethal concentration of actin inhibitors, such as cytochalasin or latrunculin, cause actin cytoskeletal destabilization and G1 phase arrest (117$119,122)$. In some cases, cells were synchronized to G1 phase using lovastatin (118) or serum-starvation (117) before cytochalasin treatment to avoid the interference of results from cells in other phases of cell cycle. Progression of G1 cells into subsequent phases of the cell cycle was monitored after adding back mevalonate, serum or epidermal growth factor (EGF). Based on these studies, it is concluded that intact actin cytoskeleton is required for responding to extracellular stimuli after the mid-G1 phase (118). Disruption of actin cytoskeleton affects cells in passing the "restriction (R)" point for S phase entry $(117,120)$. Also, once cells enter $\mathrm{S}$ phase, the phosphorylation of $\mathrm{Rb}$ and CKI p27KIP1 are not influenced by cytochalasin D treatment (118). Therefore, preservation of sufficient mechanical force for attachment and spreading by actin cytoskeleton on the solid substratum, is critical for G1 to $S$ phase transition in anchorage-dependent cells.

The cytoskeleton formed by actin filaments is an important component for cellular adherence and cell shapes. Actin filaments are primarily concentrated beneath the plasma membrane for the formation of cortical actin cytoskeleton and actin bundles. Cell anchorage and shape formation are associated with cytoskeletal tension, and they are able to induce cyclin $\mathrm{D} 1$ gene transcription for inactivating $\mathrm{Rb}$ and promoting $\mathrm{G} 1$ phase progression (13, $120,123,124)$. The cyclin E/CDK2 activity in late G1 phase and S phase entry is also influenced by cell adhesion. In contrast to cyclin D1, the cyclin E and CDK2 levels do not change significantly following cell adhesion and actin cytoskeletal formation. It is likely due to reduced expression of $\mathrm{p} 21^{\mathrm{CIP} 1}$ and $\mathrm{p} 2 \mathrm{KIP}^{\mathrm{K} 1}$ that can bind to and inhibit cyclinE/CDK2 complex, although other mechanisms are also involved $(5,123,125,126)$. Both cyclin D1 and cyclin E associated CDKs activity can inactivate $\mathrm{Rb}$ and p107 for S phase entry upon cell adhesion. Cyclin A, another important molecule responsible for $\mathrm{S}$ phase progression, can bind to CDK2 and replace the position occupied by cyclin E. Cell adhesion also promote cyclin A expression through E2F4-dependent or -independent mechanisms $(115,127)$. E2F4 is another member of E2F transcriptional factor family, and it is important for cyclin A gene transactivation (128). The E2F4-independent transactivation of cyclin A gene for S phase progression is possibly due to c-myc and CAATT binding proteins after cells attach and spread on the substratum $(129,130)$. Molecular regulations of cell adhesion and cell shape changes in G1 phase progression can be blocked by actin inhibitors that induce destabilization of actin cytoskeleton. The effects of actin cytoskeletal destabilization on cell cycle progression are usually consistent with the results of cells cultured in suspension or 
cell spreading is limited by microfabricated substrates containing fibronectin-coated adhesive islands $(116,121,124)$.

Intact actin cytoskeleton is important for $\mathrm{Rb}$ inactivation by releasing the $\mathrm{E} 2 \mathrm{~F}$ transcriptional factor for promoting DNA replication. However, the pathways that mediate actin inhibitors induced actin cytoskeletal destabilization are diverse. For instance, Huang and Ingber proposed that cytochalasin D causes down-regulation of cyclin D1 and up-regulation of p27KIP1 (118). Reshetnikova et al. found that dihydrocytochalasin B inhibited the expression of cyclin E but not cyclin D1 in Swiss 3T3 cells (117). However, the levels of p21CIP1 and p27KIP1 were not affected under the same treatment. Fasshauer et al. suggested that disorganization of actin filaments using latrunculin A, latrunculin B, or cytochalasin D leads to reduction of c-jun and cyclin (D1, E, A) expression and inhibition of entry into S phase (131). Interestingly, $\mathrm{Rb}$ and p107 double-null mouse embryo fibroblasts (MEFs) are able to reach mid-G1 phase without serum stimulation, whereas they can not transit to the $S$ phase without anchorage (121). This observation is based on a comparison of the expression of cyclin E in Rb-/-p107-/- cells between normal attachment and suspension cultured conditions. Growth factor stimulation, cytoskeletal organization and cell anchorage are essential for cyclin D1 induction and Rb phosphorylation until mid-G1 phase $(121,132,133)$. Disruption of actin cytoskeleton leads to dephosphorylation and activation of $\mathrm{Rb}$ in wildtype cells but not in RB pocket proteins-null cells. In agreement, a TKO MEF with deletions of all $\mathrm{Rb}$ pocket proteins exhibits impaired G1 phase arrest and aneuploidy following disruption of actin cytoskeleton (134). In addition, Rho small GTPase protein mediated signaling pathway is involved in actin stress fiber formation, p27KIP1 degradation and cyclin D1 expression, which promotes Rb inactivation as well as cyclin E/CDK2 activation for entry of the G1 phase $(132,133,135)$. Together, although the molecular events for actin cytoskeletal regulated G1 phase progression may be different among cell types, $\mathrm{Rb}$ family protein can be regarded as a common checkpoint molecule that allows cells with intact actin cytoskeleton passing through the G1 to S phase (Figure 4).

Several lines of evidence have shown that actin cytoskeleton may be important for cytoplasmic localization of tumor suppressor p53 during the cell cycle progression (136-138). Sequestration of p53 in the cytoplasmic portion is important for prevention of cell cycle arrest and apoptosis under normal cell growth (139). Activation of p53 by cytochalasin D was also reported, while this effect is associated with drug induced apoptosis (140). In addition, cytochalasin B can induce DNA fragmentation in specific cell types (141). On the other hand, disruption of actin cytoskeleton induced G1 phase arrest has been reported to be associated with $\mathrm{Rb}$ pocket protein rather than p53 activation (134). We also demonstrated that actin inhibitors induced a p53-independent up-regulation of $\mathrm{p} 21 \mathrm{CIP1}$ in various mammalian p53-null cancer cell lines (142). Up-regulated p21CIP1 is dependent on a posttranslational pathway to increase the protein stability and activate $\mathrm{Rb}$ for the $\mathrm{G} 1$ phase arrest. The response of p27KIP1 is relatively weak under the same condition of treatment. Taken together, it appears that different drugs used for disruption of actin filaments can activate different pathways to cause G1 phase arrest. Induction of p53-independent G1 phase arrest by actin inhibitors is especially interesting because p53 tumor suppressor is frequently inactivated or mutated in human cancers. The $\mathrm{Rb}$ tumor suppressor may play an important role in mediating the actin cytoskeletal destabilization that causes G1 phase arrest. It is also of interest to further investigate the crosstalk between p21CIP1 and $\mathrm{Rb}$ regarding toxins-induced actin cytoskeletal destabilization. 

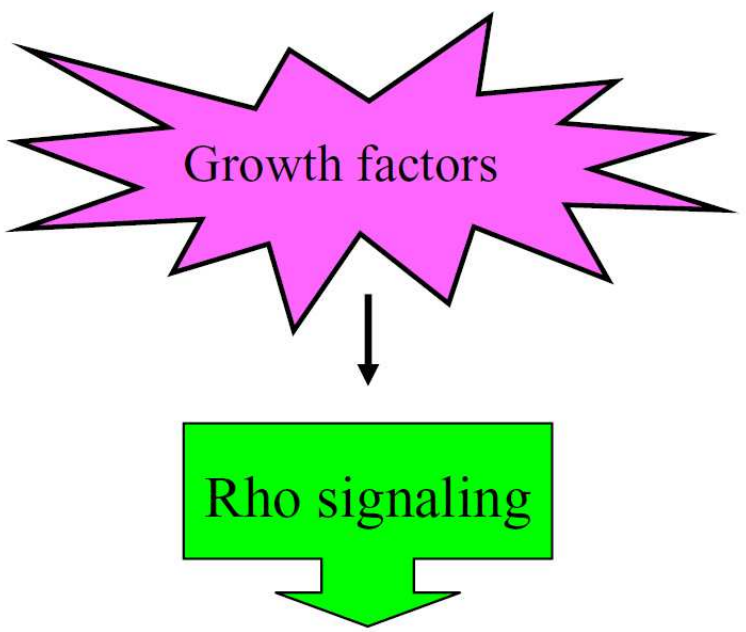

$(-)$
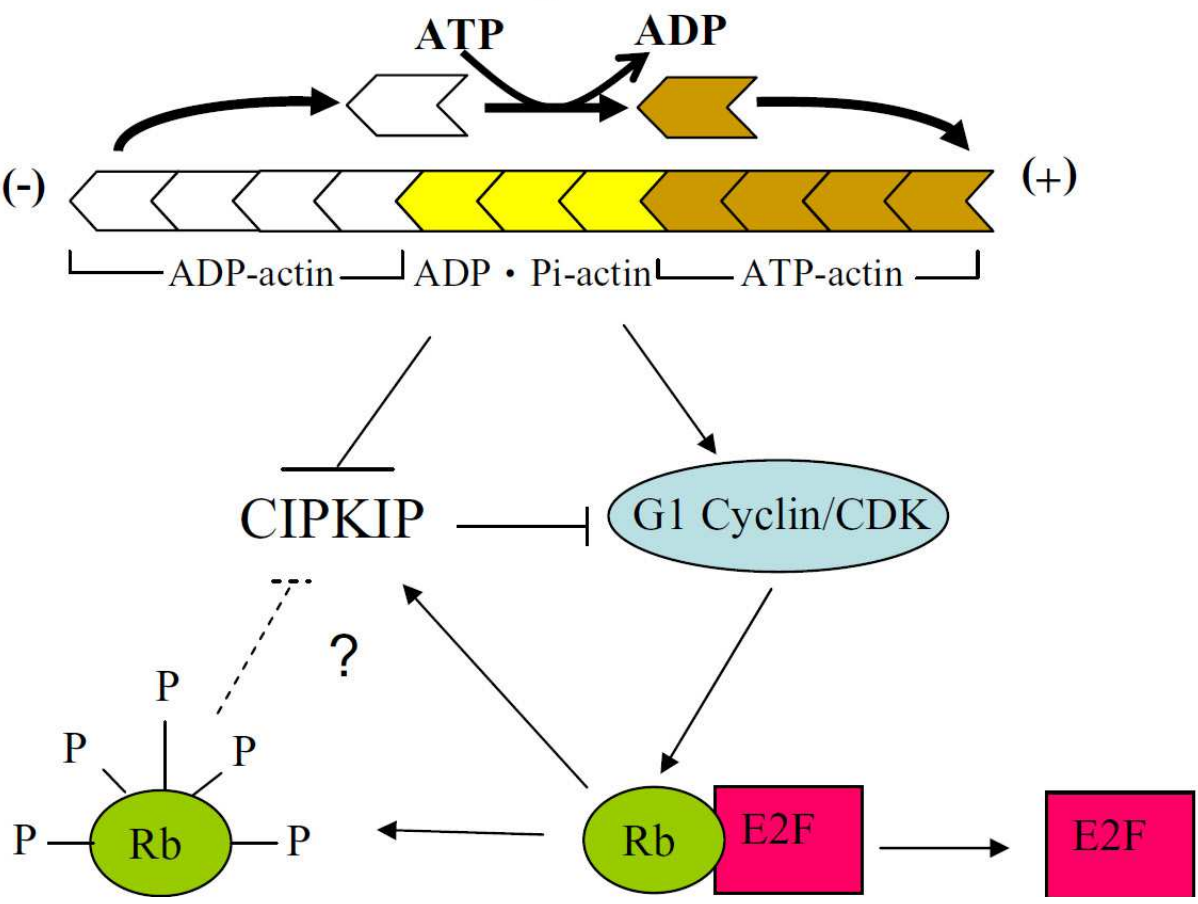

Lee $\mathrm{YJ}$ et al.

Fig. 4. Growth factor stimulated $\mathrm{Rb}$ inactivation is mediated by the actin cytoskeletal integrity. Intact actin cytoskeleton organized by the Rho signaling pathway leads to a repression of CIP/KIP family proteins and increase of G1 phase associated cyclin/CDKs activity, which can inactivate $\mathrm{Rb}$ by serine/threonine phosphorylation $(\mathrm{P})$. Activated $\mathrm{Rb}$ may increase p27KIP1 stability through a down-regulation of Skp2 gene (see text). Whether inactivated $\mathrm{Rb}$ can oppositely inhibit CIP/KIP proteins remains an opening question. 
To avoid unexpected side-effects raised by actin toxins, use of actin regulatory proteins for molecular-based destabilization of actin cytoskeleton should be an interesting approach to investigate the cell cycle effect. Since the formation of actin filaments is regulated by actinbinding proteins, forced expression of the related proteins may be able to destabilize actin filaments and influence the cell cycle distribution. Indeed, over-expression of gelsolin, an actin-regulatory protein, has been reported to activate the G2 checkpoint in human cancer cells by gene transfection (143). Over-expression of G-actin sequestrating protein thymosin $\beta-4$ also caused $S$ and G2/M phase arrest in human colon cancers (144). Moreover, overexpression of profilin-1, an actin polymerizing molecule, induces G1 phase arrest in MDAMB-231 breast cancer cell line through p27KIP1 stabilization (145). In our lab, we focused on actin dynamic regulator cofilin-1 and showed that induction of cofilin- 1 expression in human lung cancer cells led to a G1 phase arrest via p27KIP1 regulatory pathways $(39,40)$. Also, $\mathrm{Rb}$ phosphorylation is apparently reduced by forced expression of cofilin- 1 . Although destabilization of actin cytoskeleton by different actin regulatory proteins may inhibit cell cycle progression through distinct routes, it is obvious that actin cytoskeleton is important for cancer cells and would be an important target for therapeutic design.

\section{6. $\mathrm{Rb}$, actin cytoskeleton, and cancer}

$\mathrm{Rb}$ is a tumor suppressor gene, which is usually loss-of-function in a broad spectrum of human cancers $(146,147)$. The actin cytoskeletal organization induced cyclin D1 expression and $\mathrm{CDK}$ activity is essential for $\mathrm{Rb}$ phosphorylation. Destabilization of actin cytoskeleton activates $\mathrm{Rb}$ by dephosphorylation of the protein, whereas loss of $\mathrm{Rb}$ may abrogate G1 phase arrest and lead to aneuploidy for rapid cell death (134). Therefore, it seems plausible that actin inhibitors are ideal for the treatment of Rb-deficient cancers. Several different classes of actin inhibitors, such as cytochalasin and latrunculin, have been subjected to the clinical chemotherapy trial $(148,149)$. Because $\mathrm{Rb}$ is not mutated in normal tissues, these actin inhibitors may exhibit selective activities between the cancer mass and surrounding tissues. Moreover, we have recently found that latrunculin can increase the radiosensitivity in human lung cancer cell lines (unpublished data). Although the underlying mechanisms remain to be addressed, we expect that latrunculin can be used as a radiosensitizer for cancer treatment. In fact, we have shown that over-expression of cofilin- 1 can destabilize actin architectures and increase the cellular radiosensitivity by suppressing the DNA repair capacity (150). Up-regulation of cofilin-1 was also found in cells exposed to latrunculin (unpublished data), suggesting that actin inhibitor can suppress cytoskeletal dynamics and DNA damage responses consequently.

Phosphorylation of $\mathrm{Rb}$ is mainly dependent on G1 cyclin associated CDKs, which is also controlled by CKIs. The CIP/KIP family proteins are found to be up-regulated by actin inhibitors. The stabilities rather than mRNA levels of these proteins are usually increased after destabilization of actin cytoskeleton or by limiting the cell anchorage and spreading. It has been reported that $\mathrm{p} 27 \mathrm{KIP1}$ coordinates with $\mathrm{CDK}$ and $\mathrm{Rb}$ to control the proliferation and migration in vascular smooth muscle cells and fibroblasts (151). Interestingly, recent studies propose that $\mathrm{Rb}$ can reversely influence the $\mathrm{p} 27 \mathrm{KIP} 1$ expression through inhibition of Skp2, a pivotal molecule required for p27KIP1 degradation $(4,152)$. Analysis of the promoter of Skp2 gene showed that an E2F binding site was essential for gene transcription (4). Therefore, it becomes clear that p27KIP1 level should be ablated by Rb-E2F during G1/S phase transition 
depending on the cyclin E/CDK2 activity. Activation of $\mathrm{Rb}$ is sufficient to suppress Skp2 expression and increase $\mathrm{p} 2 \mathrm{KKIP}^{1}$ stability. Therefore, it is speculated that disruption of actin cytoskeleton can also trigger the Rb-Skp2-p27KIP1 auto-regulatory circuit and inhibit G1/S phase transition. Skp2 has been found to be over-expressed in several cancers $(153,154)$. Targeting on Skp2 has been reported to suppress the tumorigenesis (155). Whether use of actin inhibitors can also repress Skp2 expression would be an interesting direction for investigation. In Rb-deficiency cancer cells, disruption of actin cytoskeleton may overlook the checkpoint by excessive suppression of p27KIP1 expression for apoptosis (134). Overexpressed Skp2, although it may promote tumorigenesis, may become a reversed knife to induce death of cancer lacking $\mathrm{Rb}$ expression following disruption of actin architectures.

Metastasis is the primary cause of cancer mortality, and Rho-mediated actin reorganization is believed to be essential for enhanced cancer cell motility. The CIP/KIP family proteins have been reported to regulate molecules of Rho signaling pathway when they are relocalized to the cytoplasm from the nucleus (3). For instance, p27KIP1 can bind to Rho small GTPase (93), p21CIP1 binds to Rho kinase (ROCK) (156) and p57kip2 binds to LIMK for actin reorganization (157). All of these events may increase cell motility by activating cofilin- 1 for promoting the actin dynamics at the leading edges. Also, lack of nuclear CIP/KIP proteins may concomitantly inactivate $\mathrm{Rb}$ and enhance cell cycle progression. Whether disruption of actin cytoskeleton can affect cytoplasmic CIP/KIP and subsequently reactivate $\mathrm{Rb}$ is of interest to be further investigated. It is speculated that reactivation of $\mathrm{Rb}$ by nuclear relocalization of CIP/KIP proteins in cancer cells can be achieved by treatment with actin inhibitors.

\section{Conclusion and perspectives}

More than five thousand of research publications have been dedicated to $\mathrm{Rb}$ and tumorigenesis in the passed two decades. As the first identified tumor suppressor gene, it is no doubt that $\mathrm{Rb}$ is an important target for designing new cancer therapeutic agents. Studies of actin cytoskeletal organization in cell anchorage and spreading have greatly improved the understanding of the relationship between growth factors mediated cell cycle progression and $\mathrm{Rb}$ inactivation. Since disruption of actin cytoskeleton is known to activate $\mathrm{Rb}$ and block G1 phase progression, the actin inhibitors may prevent cancer growth. Especially, activated $\mathrm{Rb}$ can repress Skp2 oncogene and increase the stability of p27KIP1, which is a consequence of actin cytoskeletal disruption. Also, actin inhibitors may promote aneuploidy and death in $\mathrm{Rb}$-deficient cancer cells. Although targeting on actin cytoskeleton and consequent Rbrelated pathways provides a promising future in cancer treatment, several critical problems remain to be noticed and addressed: (1) It is not clear whether actin inhibitors can efficiently distinguish the malignancy from normal tissues? What is the optimal dose for cancer prevention with minimum damage to normal tissues? (2) Will actin inhibitors induce genomic instability and mutation in malignancy, especially for those that lack $\mathrm{Rb}$ expression? (3) Since actin inhibitors not only block G1 phase progression but also G2/M and cytokinesis, it is unclear whether $\mathrm{Rb}$ is also involved in the checkpoints of different phases of the cell cycle after actin inhibitor treatment? (4) It is of interest to know whether actin inhibitors can affect the expression or activity of actin-binding proteins on the cell cycle perturbation. Do actin inhibitors affect $\mathrm{Rb}$ activity through signaling pathways that regulates specific actin-binding proteins? (5) Does altered expression of actin-binding 
proteins influence $\mathrm{Rb}$ activity? If yes, what are the potential molecular mechanisms? These questions are involved but not limited to the further exploration of the interactions between actin cytoskeletal organization and Rb biology. It is believed that a comprehensive study of actin skeleton and $\mathrm{Rb}$, and related pathways and mechanisms will broaden the view of $\mathrm{Rb}$ biology on cancer treatment.

\section{Acknowledgments}

This chapter was granted by National Science Council of Taiwan, R.O.C. (NSC99-2314-B010-029-MY3)

\section{References}

[1] Frixione E: Recurring views on the structure and function of the cytoskeleton: a 300-year epic. Cell Motil Cytoskeleton. 46(2): 73-94, 2000.

[2] Sherr CJ and Roberts JM: CDK inhibitors: positive and negative regulators of G1-phase progression. Genes Dev. 13(12): 1501-1512, 1999.

[3] Besson A, Dowdy SF and Roberts JM: CDK inhibitors: cell cycle regulators and beyond. Dev Cell. 14(2): 159-169, 2008.

[4] Yung Y, Walker JL, Roberts JM and Assoian RK: A Skp2 autoinduction loop and restriction point control. J Cell Biol. 178(5): 741-747, 2007.

[5] Fang F, Orend G, Watanabe N, Hunter T and Ruoslahti E: Dependence of cyclin E-CDK2 kinase activity on cell anchorage. Science. 271(5248): 499-502, 1996.

[6] Tapon N and Hall A: Rho, Rac and Cdc42 GTPases regulate the organization of the actin cytoskeleton. Curr Opin Cell Biol. 9(1): 86-92, 1997.

[7] Burridge K, Fath K, Kelly T, Nuckolls G and Turner C: Focal adhesions: transmembrane junctions between the extracellular matrix and the cytoskeleton. Annu Rev Cell Biol. 4(487-525, 1988.

[8] Schlaepfer DD and Hunter T: Signal transduction from the extracellular matrix--a role for the focal adhesion protein-tyrosine kinase FAK. Cell Struct Funct. 21(5): 445450, 1996.

[9] Chen HC, Appeddu PA, Isoda H and Guan JL: Phosphorylation of tyrosine 397 in focal adhesion kinase is required for binding phosphatidylinositol 3-kinase. J Biol Chem. 271(42): 26329-26334, 1996.

[10] Zhao JH, Reiske H and Guan JL: Regulation of the cell cycle by focal adhesion kinase. J Cell Biol. 143(7): 1997-2008, 1998.

[11] Chen Q, Kinch MS, Lin TH, Burridge K and Juliano RL: Integrin-mediated cell adhesion activates mitogen-activated protein kinases. J Biol Chem. 269(43): 26602-26605, 1994.

[12] Yamada KM and Miyamoto S: Integrin transmembrane signaling and cytoskeletal control. Curr Opin Cell Biol. 7(5): 681-689, 1995.

[13] Assoian RK and Zhu X: Cell anchorage and the cytoskeleton as partners in growth factor dependent cell cycle progression. Curr Opin Cell Biol. 9(1): 93-98, 1997.

[14] Maness PF and Walsh RC, Jr.: Dihydrocytochalasin B disorganizes actin cytoarchitecture and inhibits initiation of DNA synthesis in 3T3 cells. Cell. 30(1): 253-262, 1982.

[15] Strome S: Determination of cleavage planes. Cell. 72(1): 3-6, 1993. 
[16] Guizetti J and Gerlich DW: Cytokinetic abscission in animal cells. Semin Cell Dev Biol. 21(9): 909-916, 2010.

[17] Kondo T, Hamao K, Kamijo K, Kimura H, Morita M, Takahashi M and Hosoya H: Enhancement of myosin II/actin turnover at the contractile ring induces slower furrowing in dividing HeLa cells. Biochem J. 435(3): 569-576, 2011.

[18] Robinson DN and Spudich JA: Mechanics and regulation of cytokinesis. Curr Opin Cell Biol. 16(2): 182-188, 2004.

[19] Clayton L and Lloyd CW: Actin organization during the cell cycle in meristematic plant cells. Actin is present in the cytokinetic phragmoplast. Exp Cell Res. 156(1): 231238, 1985.

[20] Seagull RW, Falconer MM and Weerdenburg CA: Microfilaments: dynamic arrays in higher plant cells. J Cell Biol. 104(4): 995-1004, 1987.

[21] Tiwari SC, Wick SM, Williamson RE and Gunning BE: Cytoskeleton and integration of cellular function in cells of higher plants. J Cell Biol. 99(1 Pt 2): 63s-69s, 1984.

[22] Palevitz BA: Actin in the preprophase band of Allium cepa. J Cell Biol. 104(6): 15151519, 1987.

[23] Sanger JW and Holtzer H: Cytochalasin-B: effects on cytokinesis, glycogen and 3 H-Dgluconse incorporation. Am J Anat. 135(2): 293-298, 1972.

[24] Estensen RD: Cytochalasin B. I. Effect on cytokinesis of Novikoff hepatoma cells. Proc Soc Exp Biol Med. 136(4): 1256-1260, 1971.

[25] Estensen RD, Rosenberg M, Sheridan JD, Wessells NK, Spooner BS, Ash JF, Luduena MA and Wrenn JT: Cytochalasin B: microfilaments and "contractile" processes. Science. 173(3994): 356-359, 1971.

[26] Ji JY, Haghnia M, Trusty C, Goldstein LS and Schubiger G: A genetic screen for suppressors and enhancers of the Drosophila cdk1-cyclin B identifies maternal factors that regulate microtubule and microfilament stability. Genetics. 162(3): 1179-1195, 2002.

[27] von Dassow G and Schubiger G: How an actin network might cause fountain streaming and nuclear migration in the syncytial Drosophila embryo. J Cell Biol. 127(6 Pt 1): 1637-1653, 1994.

[28] Cowan CR and Hyman AA: Acto-myosin reorganization and PAR polarity in C. elegans. Development. 134(6): 1035-1043, 2007.

[29] Na J and Zernicka-Goetz M: Asymmetric positioning and organization of the meiotic spindle of mouse oocytes requires CDC42 function. Curr Biol. 16(12): 1249-1254, 2006.

[30] Schuh $\mathrm{M}$ and Ellenberg J: A new model for asymmetric spindle positioning in mouse oocytes. Curr Biol. 18(24): 1986-1992, 2008.

[31] Wang L, Wang ZB, Zhang X, FitzHarris G, Baltz JM, Sun QY and Liu XJ: Brefeldin A disrupts asymmetric spindle positioning in mouse oocytes. Dev Biol. 313(1): 155166, 2008.

[32] Woolner S, O'Brien LL, Wiese C and Bement WM: Myosin-10 and actin filaments are essential for mitotic spindle function. J Cell Biol. 182(1): 77-88, 2008.

[33] Lenart P, Bacher CP, Daigle N, Hand AR, Eils R, Terasaki M and Ellenberg J: A contractile nuclear actin network drives chromosome congression in oocytes. Nature. 436(7052): 812-818, 2005.

[34] Kunda P and Baum B: The actin cytoskeleton in spindle assembly and positioning. Trends Cell Biol. 19(4): 174-179, 2009. 
[35] Gachet Y, Tournier S, Millar JB and Hyams JS: A MAP kinase-dependent actin checkpoint ensures proper spindle orientation in fission yeast. Nature. 412(6844): 352-355, 2001.

[36] Schmit AC and Lambert AM: Characterization and dynamics of cytoplasmic F-actin in higher plant endosperm cells during interphase, mitosis, and cytokinesis. J Cell Biol. 105(5): 2157-2166, 1987.

[37] Gurniak CB, Perlas E and Witke W: The actin depolymerizing factor n-cofilin is essential for neural tube morphogenesis and neural crest cell migration. Dev Biol. 278(1): 231-241, 2005.

[38] Bellenchi GC, Gurniak CB, Perlas E, Middei S, Ammassari-Teule M and Witke W: Ncofilin is associated with neuronal migration disorders and cell cycle control in the cerebral cortex. Genes Dev. 21(18): 2347-2357, 2007.

[39] Tsai CH, Chiu SJ, Liu CC, Sheu TJ, Hsieh CH, Keng PC and Lee YJ: Regulated expression of cofilin and the consequent regulation of p27(kip1) are essential for G(1) phase progression. Cell Cycle. 8(15): 2365-2374, 2009.

[40] Lee YJ and Keng PC: Studying the effects of actin cytoskeletal destabilization on cell cycle by cofilin overexpression. Mol Biotechnol. 31(1): 1-10, 2005.

[41] Peter M, Heitlinger E, Haner M, Aebi U and Nigg EA: Disassembly of in vitro formed lamin head-to-tail polymers by CDC2 kinase. Embo J. 10(6): 1535-1544, 1991.

[42] Hartwell LH and Kastan MB: Cell cycle control and cancer. Science. 266(5192): 18211828, 1994.

[43] Cheng M, Olivier P, Diehl JA, Fero M, Roussel MF, Roberts JM and Sherr CJ: The p21(Cip1) and p27(Kip1) CDK 'inhibitors' are essential activators of cyclin Ddependent kinases in murine fibroblasts. EMBO J. 18(6): 1571-1583, 1999.

[44] Ren S and Rollins BJ: Cyclin C/cdk3 promotes Rb-dependent G0 exit. Cell. 117(2): 239251, 2004.

[45] Bartek J and Lukas J: Are all cancer genes equal? Nature. 411(6841): 1001-1002, 2001.

[46] Gjetting T, Lukas J, Bartek J and Strauss M: Regulated expression of the retinoblastoma susceptibility gene in mammary carcinoma cells restores cyclin D1 expression and G1-phase control. Biol Chem Hoppe Seyler. 376(7): 441-446, 1995.

[47] Lukas J, Bartkova J, Rohde M, Strauss M and Bartek J: Cyclin D1 is dispensable for G1 control in retinoblastoma gene-deficient cells independently of cdk4 activity. Mol Cell Biol. 15(5): 2600-2611, 1995.

[48] Nevins JR: The Rb/E2F pathway and cancer. Hum Mol Genet. 10(7): 699-703, 2001.

[49] Lundberg AS and Weinberg RA: Functional inactivation of the retinoblastoma protein requires sequential modification by at least two distinct cyclin-cdk complexes. Mol Cell Biol. 18(2): 753-761, 1998.

[50] DeGregori J, Kowalik T and Nevins JR: Cellular targets for activation by the E2F1 transcription factor include DNA synthesis- and G1/S-regulatory genes. Mol Cell Biol. 15(8): 4215-4224, 1995.

[51] Stanelle J, Stiewe T, Theseling CC, Peter M and Putzer BM: Gene expression changes in response to E2F1 activation. Nucleic Acids Res. 30(8): 1859-1867, 2002.

[52] Knudsen ES and Wang JY: Dual mechanisms for the inhibition of E2F binding to RB by cyclin-dependent kinase-mediated RB phosphorylation. Mol Cell Biol. 17(10): 57715783, 1997.

[53] Chew YP, Ellis M, Wilkie S and Mittnacht S: pRB phosphorylation mutants reveal role of $\mathrm{pRB}$ in regulating $\mathrm{S}$ phase completion by a mechanism independent of E2F. Oncogene. 17(17): 2177-2186, 1998. 
[54] Sever-Chroneos Z, Angus SP, Fribourg AF, Wan H, Todorov I, Knudsen KE and Knudsen ES: Retinoblastoma tumor suppressor protein signals through inhibition of cyclin-dependent kinase 2 activity to disrupt PCNA function in S phase. Mol Cell Biol. 21(12): 4032-4045, 2001.

[55] Masselli A and Wang JY: Phosphorylation site mutated RB exerts contrasting effects on apoptotic response to different stimuli. Oncogene. 25(9): 1290-1298, 2006.

[56] Wang JY, Naderi S and Chen TT: Role of retinoblastoma tumor suppressor protein in DNA damage response. Acta Oncol. 40(6): 689-695, 2001.

[57] Wang S, Nath N, Minden A and Chellappan S: Regulation of Rb and E2F by signal transduction cascades: divergent effects of JNK1 and p38 kinases. EMBO J. 18(6): 1559-1570, 1999.

[58] Dasgupta P, Sun J, Wang S, Fusaro G, Betts V, Padmanabhan J, Sebti SM and Chellappan SP: Disruption of the Rb--Raf-1 interaction inhibits tumor growth and angiogenesis. Mol Cell Biol. 24(21): 9527-9541, 2004.

[59] Nath N, Wang S, Betts V, Knudsen E and Chellappan S: Apoptotic and mitogenic stimuli inactivate $\mathrm{Rb}$ by differential utilization of p38 and cyclin-dependent kinases. Oncogene. 22(38): 5986-5994, 2003.

[60] Singh S, Johnson J and Chellappan S: Small molecule regulators of Rb-E2F pathway as modulators of transcription. Biochim Biophys Acta. 1799(10-12): 788-794, 2010.

[61] Naderi S, Hunton IC and Wang JY: Radiation dose-dependent maintenance of G(2) arrest requires retinoblastoma protein. Cell Cycle. 1(3): 193-200, 2002.

[62] Santamaria D, Barriere C, Cerqueira A, Hunt S, Tardy C, Newton K, Caceres JF, Dubus $\mathrm{P}$, Malumbres $\mathrm{M}$ and Barbacid M: Cdk1 is sufficient to drive the mammalian cell cycle. Nature. 448(7155): 811-815, 2007.

[63] Ludlow JW, Glendening CL, Livingston DM and DeCarprio JA: Specific enzymatic dephosphorylation of the retinoblastoma protein. Mol Cell Biol. 13(1): 367-372, 1993.

[64] Sterner JM, Murata Y, Kim HG, Kennett SB, Templeton DJ and Horowitz JM: Detection of a novel cell cycle-regulated kinase activity that associates with the amino terminus of the retinoblastoma protein in G2/M phases. J Biol Chem. 270(16): 92819288, 1995.

[65] Sterner JM, Tao Y, Kennett SB, Kim HG and Horowitz JM: The amino terminus of the retinoblastoma $(\mathrm{Rb})$ protein associates with a cyclin-dependent kinase-like kinase via $\mathrm{Rb}$ amino acids required for growth suppression. Cell Growth Differ. 7(1): 5364, 1996.

[66] Cobrinik D: Pocket proteins and cell cycle control. Oncogene. 24(17): 2796-2809, 2005.

[67] Sherr CJ and McCormick F: The RB and p53 pathways in cancer. Cancer Cell. 2(2): 103112, 2002.

[68] Saddic LA, West LE, Aslanian A, Yates JR, 3rd, Rubin SM, Gozani O and Sage J: Methylation of the retinoblastoma tumor suppressor by SMYD2. J Biol Chem. 285(48): 37733-37740, 2010.

[69] Ianari A and Gulino A: Cell death or survival: the complex choice of the retinoblastoma tumor suppressor protein. Cell Cycle. 9(1): 23-24, 2010.

[70] Sharma A, Yeow WS, Ertel A, Coleman I, Clegg N, Thangavel C, Morrissey C, Zhang X, Comstock CE, Witkiewicz AK, Gomella L, Knudsen ES, Nelson PS and Knudsen KE: The retinoblastoma tumor suppressor controls androgen signaling and human prostate cancer progression. J Clin Invest. 120(12): 4478-4492, 2010. 
[71] Knudsen ES and Knudsen KE: Retinoblastoma tumor suppressor: where cancer meets the cell cycle. Exp Biol Med (Maywood). 231(7): 1271-1281, 2006.

[72] Knudsen ES, Sexton CR and Mayhew CN: Role of the retinoblastoma tumor suppressor in the maintenance of genome integrity. Curr Mol Med. 6(7): 749-757, 2006.

[73] Lee JO, Russo AA and Pavletich NP: Structure of the retinoblastoma tumour-suppressor pocket domain bound to a peptide from HPV E7. Nature. 391(6670): 859-865, 1998.

[74] Dunaief JL, Strober BE, Guha S, Khavari PA, Alin K, Luban J, Begemann M, Crabtree GR and Goff SP: The retinoblastoma protein and BRG1 form a complex and cooperate to induce cell cycle arrest. Cell. 79(1): 119-130, 1994.

[75] Singh P, Coe J and Hong W: A role for retinoblastoma protein in potentiating transcriptional activation by the glucocorticoid receptor. Nature. 374(6522): 562565, 1995.

[76] Gray SG, Iglesias AH, Lizcano F, Villanueva R, Camelo S, Jingu H, Teh BT, Koibuchi N, Chin WW, Kokkotou E and Dangond F: Functional characterization of JMJD2A, a histone deacetylase- and retinoblastoma-binding protein. J Biol Chem. 280(31): 28507-28518, 2005.

[77] Chen D, Pacal M, Wenzel P, Knoepfler PS, Leone G and Bremner R: Division and apoptosis of E2f-deficient retinal progenitors. Nature. 462(7275): 925-929, 2009.

[78] Zhang H, Xiong $\mathrm{Y}$ and Beach D: Proliferating cell nuclear antigen and p21 are components of multiple cell cycle kinase complexes. Mol Biol Cell. 4(9): 897-906, 1993.

[79] Polyak K, Lee MH, Erdjument-Bromage H, Koff A, Roberts JM, Tempst P and Massague J: Cloning of p27Kip1, a cyclin-dependent kinase inhibitor and a potential mediator of extracellular antimitogenic signals. Cell. 78(1): 59-66, 1994.

[80] Toyoshima H and Hunter T: p27, a novel inhibitor of G1 cyclin-Cdk protein kinase activity, is related to p21. Cell. 78(1): 67-74, 1994.

[81] Xiong Y, Zhang H and Beach D: Subunit rearrangement of the cyclin-dependent kinases is associated with cellular transformation. Genes Dev. 7(8): 1572-1583, 1993.

[82] Parry DA and Steinert PM: Intermediate filaments: molecular architecture, assembly, dynamics and polymorphism. Q Rev Biophys. 32(2): 99-187, 1999.

[83] Reynisdottir I and Massague J: The subcellular locations of p15(Ink4b) and p27(Kip1) coordinate their inhibitory interactions with cdk4 and cdk2. Genes Dev. 11(4): 492$503,1997$.

[84] McConnell BB, Gregory FJ, Stott FJ, Hara E and Peters G: Induced expression of p16(INK4a) inhibits both CDK4- and CDK2-associated kinase activity by reassortment of cyclin-CDK-inhibitor complexes. Mol Cell Biol. 19(3): 1981-1989, 1999.

[85] Canepa ET, Scassa ME, Ceruti JM, Marazita MC, Carcagno AL, Sirkin PF and Ogara MF: INK4 proteins, a family of mammalian CDK inhibitors with novel biological functions. IUBMB Life. 59(7): 419-426, 2007.

[86] Zou X, Ray D, Aziyu A, Christov K, Boiko AD, Gudkov AV and Kiyokawa H: Cdk4 disruption renders primary mouse cells resistant to oncogenic transformation, leading to Arf/p53-independent senescence. Genes Dev. 16(22): 2923-2934, 2002.

[87] Slingerland J and Pagano M: Regulation of the cdk inhibitor p27 and its deregulation in cancer. J Cell Physiol. 183(1): 10-17, 2000.

[88] Philipp-Staheli J, Payne SR and Kemp CJ: p27(Kip1): regulation and function of a haploinsufficient tumor suppressor and its misregulation in cancer. Exp Cell Res. 264(1): 148-168, 2001. 
[89] Liang J, Zubovitz J, Petrocelli T, Kotchetkov R, Connor MK, Han K, Lee JH, Ciarallo S, Catzavelos C, Beniston R, Franssen E and Slingerland JM: PKB/Akt phosphorylates p27, impairs nuclear import of p27 and opposes p27-mediated G1 arrest. Nat Med. 8(10): 1153-1160, 2002.

[90] Besson A, Assoian RK and Roberts JM: Regulation of the cytoskeleton: an oncogenic function for CDK inhibitors? Nat Rev Cancer. 4(12): 948-955, 2004.

[91] Biankin AV, Kench JG, Morey AL, Lee CS, Biankin SA, Head DR, Hugh TB, Henshall SM and Sutherland RL: Overexpression of p21(WAF1/CIP1) is an early event in the development of pancreatic intraepithelial neoplasia. Cancer Res. 61(24): 88308837, 2001.

[92] Roninson IB: Oncogenic functions of tumour suppressor p21(Waf1/Cip1/Sdi1): association with cell senescence and tumour-promoting activities of stromal fibroblasts. Cancer Lett. 179(1): 1-14, 2002.

[93] Besson A, Gurian-West M, Schmidt A, Hall A and Roberts JM: p27Kip1 modulates cell migration through the regulation of RhoA activation. Genes Dev. 18(8): 862-876, 2004.

[94] Gartel AL and Tyner AL: Transcriptional regulation of the p21((WAF1/CIP1)) gene. Exp Cell Res. 246(2): 280-289, 1999.

[95] el-Deiry WS, Tokino T, Velculescu VE, Levy DB, Parsons R, Trent JM, Lin D, Mercer WE, Kinzler KW and Vogelstein B: WAF1, a potential mediator of p53 tumor suppression. Cell. 75(4): 817-825, 1993.

[96] Macleod KF, Sherry N, Hannon G, Beach D, Tokino T, Kinzler K, Vogelstein B and Jacks $\mathrm{T}$ : p53-dependent and independent expression of p21 during cell growth, differentiation, and DNA damage. Genes Dev. 9(8): 935-944, 1995.

[97] Namba H, Hara T, Tukazaki T, Migita K, Ishikawa N, Ito K, Nagataki S and Yamashita S: Radiation-induced G1 arrest is selectively mediated by the p53-WAF1/Cip1 pathway in human thyroid cells. Cancer Res. 55(10): 2075-2080, 1995.

[98] Dulic V, Kaufmann WK, Wilson SJ, Tlsty TD, Lees E, Harper JW, Elledge SJ and Reed SI: p53-dependent inhibition of cyclin-dependent kinase activities in human fibroblasts during radiation-induced G1 arrest. Cell. 76(6): 1013-1023, 1994.

[99] Nakayama K: Cip/Kip cyclin-dependent kinase inhibitors: brakes of the cell cycle engine during development. Bioessays. 20(12): 1020-1029, 1998.

[100] Sheaff RJ, Groudine M, Gordon M, Roberts JM and Clurman BE: Cyclin E-CDK2 is a regulator of p27Kip1. Genes Dev. 11(11): 1464-1478, 1997.

[101] Pagano M, Tam SW, Theodoras AM, Beer-Romero P, Del Sal G, Chau V, Yew PR, Draetta GF and Rolfe M: Role of the ubiquitin-proteasome pathway in regulating abundance of the cyclin-dependent kinase inhibitor p27. Science. 269(5224): 682685, 1995.

[102] Carrano AC and Pagano M: Role of the F-box protein Skp2 in adhesion-dependent cell cycle progression. J Cell Biol. 153(7): 1381-1390, 2001.

[103] Ishida N, Kitagawa M, Hatakeyama S and Nakayama K: Phosphorylation at serine 10, a major phosphorylation site of p27(Kip1), increases its protein stability. J Biol Chem. 275(33): 25146-25154, 2000.

[104] Besson A, Gurian-West M, Chen X, Kelly-Spratt KS, Kemp CJ and Roberts JM: A pathway in quiescent cells that controls p27Kip1 stability, subcellular localization, and tumor suppression. Genes Dev. 20(1): 47-64, 2006.

[105] Connor MK, Kotchetkov R, Cariou S, Resch A, Lupetti R, Beniston RG, Melchior F, Hengst L and Slingerland JM: CRM1/Ran-mediated nuclear export of p27(Kip1) 
involves a nuclear export signal and links p27 export and proteolysis. Mol Biol Cell. 14(1): 201-213, 2003.

[106] Rodier G, Montagnoli A, Di Marcotullio L, Coulombe P, Draetta GF, Pagano M and Meloche S: p27 cytoplasmic localization is regulated by phosphorylation on Ser10 and is not a prerequisite for its proteolysis. EMBO J. 20(23): 6672-6682, 2001.

[107] McAllister SS, Becker-Hapak M, Pintucci G, Pagano M and Dowdy SF: Novel p27(kip1) C-terminal scatter domain mediates Rac-dependent cell migration independent of cell cycle arrest functions. Mol Cell Biol. 23(1): 216-228, 2003.

[108] Fujita N, Sato S and Tsuruo T: Phosphorylation of p27Kip1 at threonine 198 by p90 ribosomal protein S6 kinases promotes its binding to 14-3-3 and cytoplasmic localization. J Biol Chem. 278(49): 49254-49260, 2003.

[109] Sekimoto T, Fukumoto M and Yoneda Y: 14-3-3 suppresses the nuclear localization of threonine 157-phosphorylated p27(Kip1). EMBO J. 23(9): 1934-1942, 2004.

[110] Bunz F, Dutriaux A, Lengauer C, Waldman T, Zhou S, Brown JP, Sedivy JM, Kinzler KW and Vogelstein B: Requirement for p53 and p21 to sustain G2 arrest after DNA damage. Science. 282(5393): 1497-1501, 1998.

[111] Levine AJ: p53, the cellular gatekeeper for growth and division. Cell. 88(3): 323-331, 1997.

[112] Waning DL, Lehman JA, Batuello CN and Mayo LD: Controlling the Mdm2-Mdmxp53 Circuit. Pharmaceuticals (Basel). 3(5): 1576-1593, 2010.

[113] Jin S and Levine AJ: The p53 functional circuit. J Cell Sci. 114(Pt 23): 4139-4140, 2001.

[114] Shieh SY, Ikeda M, Taya Y and Prives C: DNA damage-induced phosphorylation of p53 alleviates inhibition by MDM2. Cell. 91(3): 325-334, 1997.

[115] Assoian RK: Anchorage-dependent cell cycle progression. J Cell Biol. 136(1): 1-4, 1997.

[116] Huang S and Ingber DE: The structural and mechanical complexity of cell-growth control. Nat Cell Biol. 1(5): E131-138, 1999.

[117] Reshetnikova G, Barkan R, Popov B, Nikolsky N and Chang LS: Disruption of the actin cytoskeleton leads to inhibition of mitogen-induced cyclin E expression, Cdk2 phosphorylation, and nuclear accumulation of the retinoblastoma protein-related p107 protein. Exp Cell Res. 259(1): 35-53, 2000.

[118] Huang S and Ingber DE: A discrete cell cycle checkpoint in late $G(1)$ that is cytoskeleton-dependent and MAP kinase (Erk)-independent. Exp Cell Res. 275(2): 255-264, 2002.

[119] Iwig M, Czeslick E, Muller A, Gruner M, Spindler M and Glaesser D: Growth regulation by cell shape alteration and organization of the cytoskeleton. Eur J Cell Biol. 67(2): 145-157, 1995.

[120] Bohmer RM, Scharf E and Assoian RK: Cytoskeletal integrity is required throughout the mitogen stimulation phase of the cell cycle and mediates the anchoragedependent expression of cyclin D1. Mol Biol Cell. 7(1): 101-111, 1996.

[121] Gad A, Thullberg M, Dannenberg JH, te Riele H and Stromblad S: Retinoblastoma susceptibility gene product $(\mathrm{pRb})$ and p107 functionally separate the requirements for serum and anchorage in the cell cycle G1-phase. J Biol Chem. 279(14): 1364013644, 2004.

[122] Westermark B: Induction of a reversible G1 block in human glia-like cells by cytochalasin B. Exp Cell Res. 82(2): 341-350, 1973.

[123] Zhu X, Ohtsubo M, Bohmer RM, Roberts JM and Assoian RK: Adhesion-dependent cell cycle progression linked to the expression of cyclin D1, activation of cyclin E- 
cdk2, and phosphorylation of the retinoblastoma protein. J Cell Biol. 133(2): 391403, 1996.

[124] Huang S, Chen CS and Ingber DE: Control of cyclin D1, p27(Kip1), and cell cycle progression in human capillary endothelial cells by cell shape and cytoskeletal tension. Mol Biol Cell. 9(11): 3179-3193, 1998.

[125] Carstens CP, Kramer A and Fahl WE: Adhesion-dependent control of cyclin E/cdk2 activity and cell cycle progression in normal cells but not in Ha-ras transformed NRK cells. Exp Cell Res. 229(1): 86-92, 1996.

[126] Kang JS and Krauss RS: Ras induces anchorage-independent growth by subverting multiple adhesion-regulated cell cycle events. Mol Cell Biol. 16(7): 3370-3380, 1996.

[127] Schulze A, Zerfass-Thome K, Berges J, Middendorp S, Jansen-Durr P and Henglein B: Anchorage-dependent transcription of the cyclin A gene. Mol Cell Biol. 16(9): 46324638, 1996.

[128] Schulze A, Zerfass K, Spitkovsky D, Middendorp S, Berges J, Helin K, Jansen-Durr P and Henglein B: Cell cycle regulation of the cyclin A gene promoter is mediated by a variant E2F site. Proc Natl Acad Sci U S A. 92(24): 11264-11268, 1995.

[129] Barrett JF, Lewis BC, Hoang AT, Alvarez RJ, Jr. and Dang CV: Cyclin A links c-Myc to adhesion-independent cell proliferation. J Biol Chem. 270(27): 15923-15925, 1995.

[130] Kramer A, Carstens CP and Fahl WE: A novel CCAAT-binding protein necessary for adhesion-dependent cyclin A transcription at the G1/S boundary is sequestered by a retinoblastoma-like protein in G0. J Biol Chem. 271(12): 6579-6582, 1996.

[131] Fasshauer M, Iwig M and Glaesser D: Synthesis of proto-oncogene proteins and cyclins depends on intact microfilaments. Eur J Cell Biol. 77(3): 188-195, 1998.

[132] Roovers K, Klein EA, Castagnino P and Assoian RK: Nuclear translocation of LIM kinase mediates Rho-Rho kinase regulation of cyclin D1 expression. Dev Cell. 5(2): 273-284, 2003.

[133] Roovers K and Assoian RK: Effects of rho kinase and actin stress fibers on sustained extracellular signal-regulated kinase activity and activation of $G(1)$ phase cyclindependent kinases. Mol Cell Biol. 23(12): 4283-4294, 2003.

[134] Lohez OD, Reynaud C, Borel F, Andreassen PR and Margolis RL: Arrest of mammalian fibroblasts in G1 in response to actin inhibition is dependent on retinoblastoma pocket proteins but not on p53. J Cell Biol. 161(1): 67-77, 2003.

[135] Hu W, Bellone CJ and Baldassare JJ: RhoA stimulates p27(Kip) degradation through its regulation of cyclin E/CDK2 activity. J Biol Chem. 274(6): 3396-3401, 1999.

[136] Metcalfe S, Weeds A, Okorokov AL, Milner J, Cockman M and Pope B: Wild-type p53 protein shows calcium-dependent binding to F-actin. Oncogene. 18(14): 2351-2355, 1999.

[137] Katsumoto T, Higaki K, Ohno K and Onodera K: Cell-cycle dependent biosynthesis and localization of p53 protein in untransformed human cells. Biol Cell. 84(3): 167173, 1995.

[138] Takahashi K and Suzuki K: DNA synthesis-associated nuclear exclusion of p53 in normal human breast epithelial cells in culture. Oncogene. 9(1): 183-188, 1994.

[139] Bates S and Vousden KH: Mechanisms of p53-mediated apoptosis. Cell Mol Life Sci. 55(1): 28-37, 1999.

[140] Rubtsova SN, Kondratov RV, Kopnin PB, Chumakov PM, Kopnin BP and Vasiliev JM: Disruption of actin microfilaments by cytochalasin D leads to activation of p53. FEBS Lett. 430(3): 353-357, 1998. 
[141] Kolber MA, Broschat KO and Landa-Gonzalez B: Cytochalasin B induces cellular DNA fragmentation. Faseb J. 4(12): 3021-3027, 1990.

[142] Lee YJ, Tsai CH, Hwang JJ, Chiu SJ, Sheu TJ and Keng PC: Involvement of a p53independent and post-transcriptional up-regulation for p21WAF/CIP1 following destabilization of the actin cytoskeleton. Int J Oncol. 34(2): 581-589, 2009.

[143] Sakai N, Ohtsu M, Fujita H, Koike T and Kuzumaki N: Enhancement of G2 checkpoint function by gelsolin transfection in human cancer cells. Exp Cell Res. 251(1): 224233, 1999.

[144] Wang WS, Chen PM, Hsiao HL, Ju SY and Su Y: Overexpression of the thymosin beta4 gene is associated with malignant progression of SW480 colon cancer cells. Oncogene. 22(21): 3297-3306, 2003.

[145] Zou L, Ding Z and Roy P: Profilin-1 overexpression inhibits proliferation of MDA-MB231 breast cancer cells partly through p27kip1 upregulation. J Cell Physiol. 223(3): 623-629, 2010.

[146] Hanahan D and Weinberg RA: The hallmarks of cancer. Cell. 100(1): 57-70, 2000.

[147] Sherr CJ: Cell cycle control and cancer. Harvey Lect. 96(73-92, 2000.

[148] Jordan MA and Wilson L: Use of drugs to study role of microtubule assembly dynamics in living cells. Methods Enzymol. 298(252-276, 1998.

[149] Lehmann KG, Popma JJ, Werner JA, Lansky AJ and Wilensky RL: Vascular remodeling and the local delivery of cytochalasin B after coronary angioplasty in humans. J Am Coll Cardiol. 35(3): 583-591, 2000.

[150] Lee YJ, Sheu TJ and Keng PC: Enhancement of radiosensitivity in H1299 cancer cells by actin-associated protein cofilin. Biochem Biophys Res Commun. 335(2): 286-291, 2005.

[151] Diez-Juan A and Andres V: Coordinate control of proliferation and migration by the p27Kip1/cyclin-dependent kinase/retinoblastoma pathway in vascular smooth muscle cells and fibroblasts. Circ Res. 92(4): 402-410, 2003.

[152] Assoian RK and Yung Y: A reciprocal relationship between Rb and Skp2: implications for restriction point control, signal transduction to the cell cycle and cancer. Cell Cycle. 7(1): 24-27, 2008.

[153] Hershko DD: Oncogenic properties and prognostic implications of the ubiquitin ligase Skp2 in cancer. Cancer. 112(7): 1415-1424, 2008.

[154] Signoretti S, Di Marcotullio L, Richardson A, Ramaswamy S, Isaac B, Rue M, Monti F, Loda $\mathrm{M}$ and Pagano M: Oncogenic role of the ubiquitin ligase subunit Skp2 in human breast cancer. J Clin Invest. 110(5): 633-641, 2002.

[155] Lin HK, Chen Z, Wang G, Nardella C, Lee SW, Chan CH, Yang WL, Wang J, Egia A, Nakayama KI, Cordon-Cardo C, Teruya-Feldstein J and Pandolfi PP: Skp2 targeting suppresses tumorigenesis by Arf-p53-independent cellular senescence. Nature. 464(7287): 374-379, 2010.

[156] Tanaka H, Yamashita T, Asada M, Mizutani S, Yoshikawa H and Tohyama M: Cytoplasmic p21(Cip1/WAF1) regulates neurite remodeling by inhibiting Rhokinase activity. J Cell Biol. 158(2): 321-329, 2002.

[157] Yokoo T, Toyoshima H, Miura M, Wang Y, Iida KT, Suzuki H, Sone H, Shimano H, Gotoda T, Nishimori S, Tanaka K and Yamada N: p57Kip2 regulates actin dynamics by binding and translocating LIM-kinase 1 to the nucleus. J Biol Chem. 278(52): 52919-52923, 2003. 


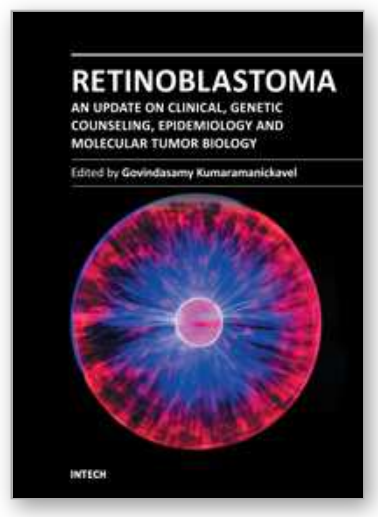

\author{
Retinoblastoma: An Update on Clinical, Genetic Counseling, \\ Epidemiology and Molecular Tumor Biology \\ Edited by Prof. Govindasamy Kumaramanickavel
}

ISBN 978-953-51-0435-3

Hard cover, 170 pages

Publisher InTech

Published online 28, March, 2012

Published in print edition March, 2012

Retinoblastoma is the first tumor suppressor gene discovered ever. The discovery opened a new avenue in the field of oncology leading to the identification of 35 tumor suppressor genes, till date in our genome. This book is an excellent compilation of both clinical and basic science information that meets the needs of a young clinician and a researcher at the same time. It also has abundant information on recent advances and cuttingedge knowledge in intracellular molecular cross-talking of retinoblastoma protein with various cellular viral-like proteins.

\title{
How to reference
}

In order to correctly reference this scholarly work, feel free to copy and paste the following:

Yi-Jang Lee, Pei-Hsun Chiang and Peter C. Keng (2012). Cytoskeletal Organization and Rb Tumor Suppressor Gene, Retinoblastoma: An Update on Clinical, Genetic Counseling, Epidemiology and Molecular Tumor Biology, Prof. Govindasamy Kumaramanickavel (Ed.), ISBN: 978-953-51-0435-3, InTech, Available from: http://www.intechopen.com/books/retinoblastoma-an-update-on-clinical-genetic-counselingepidemiology-and-molecular-tumor-biology/cytoskeletal-organization-and-rb-tumor-suppressor-gene

\section{INTECH}

open science | open minds

\section{InTech Europe}

University Campus STeP Ri

Slavka Krautzeka 83/A

51000 Rijeka, Croatia

Phone: +385 (51) 770447

Fax: +385 (51) 686166

www.intechopen.com

\section{InTech China}

Unit 405, Office Block, Hotel Equatorial Shanghai

No.65, Yan An Road (West), Shanghai, 200040, China

中国上海市延安西路65号上海国际贵都大饭店办公楼405单元

Phone: +86-21-62489820

Fax: +86-21-62489821 
(C) 2012 The Author(s). Licensee IntechOpen. This is an open access article distributed under the terms of the Creative Commons Attribution 3.0 License, which permits unrestricted use, distribution, and reproduction in any medium, provided the original work is properly cited. 